Research Article

\title{
High-Performance Grouting Mortar Based on Mineral Admixtures
}

\author{
Cong Ma, Yuehu Tan, Erbing Li, Yinsuo Dai, and Meng Yang \\ College of Defense Engineering, PLA University of Science and Technology, Nanjing 210007, China
}

Correspondence should be addressed to Yuehu Tan; tan_yuehu@163.com

Received 24 October 2014; Revised 29 December 2014; Accepted 3 February 2015

Academic Editor: Somchai Thongtem

Copyright (C) 2015 Cong Ma et al. This is an open access article distributed under the Creative Commons Attribution License, which permits unrestricted use, distribution, and reproduction in any medium, provided the original work is properly cited.

A study on high-performance grouting mortar is reported. The common mortar was modified by mineral admixtures such as gypsum, bauxite, and alunite. The effects of mineral admixtures on the fluidity, setting time, expansion, strength, and other properties of mortar were evaluated experimentally. The microstructure of the modified mortar was characterized by X-ray diffraction, scanning electron microscopy, and mercury intrusion porosimetry. Moreover, the expansive performance and strength of the grouting mortar were verified by anchor pullout test. The results show that the best conditions for gypsum-bauxite grouting mortar are as follows: a water-to-binder ratio of 0.3 , a mineral admixture content of $\sim 15 \%$, and a molar ratio $K$ of 2 . The ultimate bearing capacity of the gypsum-bauxite grouting mortar anchor increased by $39.6 \%$ compared to the common mortar anchor. The gypsum-bauxite grouting mortar has good fluidity, quick-setting, microexpansion, early strength, and high strength performances.

\section{Introduction}

Cementitious grout has widespread application in engineering because of the advantages of good durability, high strength, low cost, and environmental friendliness $[1,2]$. In recent years, the preparation and performance of grouting mortar have been extensively studied. The fluidity, water retention, and strength of mortar have been significantly improved by adding a certain amount of silica fume, volcanic ash, and other admixtures [3-8]. The strength and fluidity of grouting mortar can be improved by adding a superplasticizer, but it will shrink the volume of hardened cement pastes [9-12]. Ettringite (AFt) has expansion property. The formation of ettringite and its expansion have been studied using pastes made from an $\mathrm{Al}$-containing compound, gypsum, and tricalcium silicate [13]. After the expansive agent was added, the mortar performance was improved because of some volume expansion. Ettringite-type expansive agents have been widely used $[14,15]$. The formation and expansion of ettringite occur rapidly within a few hours [16].

However, the current studies on grouting mortar focused on one aspect of performance improvement, without considering the fluidity, setting time, expansion, strength, and economy as a whole. Thus, it is difficult to improve the comprehensive performance of grouting mortar. When an $\mathrm{Al}$-containing mineral reacts with $\mathrm{Ca}^{2+}$ and $\mathrm{SO}_{4}{ }^{2-}$, ettringite $\left(3 \mathrm{CaO} \cdot \mathrm{Al}_{2} \mathrm{O}_{3} \cdot 3 \mathrm{CaSO}_{4} \cdot 32 \mathrm{H}_{2} \mathrm{O}\right)$ is obtained. If gypsum $\left(\mathrm{CaSO}_{4} \cdot 2 \mathrm{H}_{2} \mathrm{O}\right)$ and high Al-containing minerals such as bauxite $\left(\mathrm{Al}_{2} \mathrm{O}_{3} \cdot 6 \mathrm{H}_{2} \mathrm{O}\right)$ and alunite $\left(\mathrm{KAl}_{3}\left(\mathrm{SO}_{4}\right)_{2}(\mathrm{OH})_{6}\right)$ are added to the grouting mortar, the expansion performance and setting speed of mortar are improved by the rapid generation of ettringite as shown in

$$
\begin{aligned}
& \mathrm{Al}_{2} \mathrm{O}_{3} \cdot 6 \mathrm{H}_{2} \mathrm{O}+3\left(\mathrm{CaSO}_{4} \cdot 2 \mathrm{H}_{2} \mathrm{O}\right)+3 \mathrm{Ca}(\mathrm{OH})_{2}+17 \mathrm{H}_{2} \mathrm{O} \\
& \quad=3 \mathrm{CaO} \cdot \mathrm{Al}_{2} \mathrm{O}_{3} \cdot 3 \mathrm{CaSO}_{4} \cdot 32 \mathrm{H}_{2} \mathrm{O} \\
& \mathrm{KAl}_{3}\left(\mathrm{SO}_{4}\right)_{2}(\mathrm{OH})_{6}+\mathrm{CaSO}_{4} \cdot 2 \mathrm{H}_{2} \mathrm{O}+5 \mathrm{Ca}(\mathrm{OH})_{2}+24 \mathrm{H}_{2} \mathrm{O} \\
& =3 \mathrm{CaO} \cdot \mathrm{Al}_{2} \mathrm{O}_{3} \cdot 3 \mathrm{CaSO}_{4} \cdot 32 \mathrm{H}_{2} \mathrm{O}+\mathrm{KOH}+\mathrm{Al}(\mathrm{OH})_{3}
\end{aligned}
$$

The aim of this study is to produce expansive mortars using ettringite. Moreover, the expensive mortar should have the comprehensive performance of good fluidity, quicksetting, early strength, high strength, and economy. In this study, the common mortar was modified by mineral admixtures such as gypsum, bauxite, and alunite. The effects of 
TABLE 1: Chemical composition of materials (wt\%).

\begin{tabular}{lcccccccc}
\hline Materials & $\mathrm{SO}_{3}$ & $\mathrm{CaO}$ & $\mathrm{MgO}$ & $\mathrm{SiO}_{2}$ & $\mathrm{Al}_{2} \mathrm{O}_{3}$ & $\mathrm{Fe}_{2} \mathrm{O}_{3}$ & $\mathrm{Na}_{2} \mathrm{O}+\mathrm{K}_{2} \mathrm{O}$ & Loss on ignition \\
\hline Cement & 2.91 & 63.41 & 1.67 & 21.19 & 5.46 & 2.33 & 2.50 & 1.51 \\
Gypsum & 50.43 & 37.45 & 3.71 & 2.13 & 0.53 & 0.15 & 0.24 & 5.01 \\
Bauxite & 1.95 & 28.31 & 0.48 & 5.76 & 46.96 & 2.20 & 1.00 & 11.10 \\
Alunite & 20.54 & 0.33 & 0.07 & 25.82 & 19.45 & 4.57 & 4.67 & 23.02 \\
\hline
\end{tabular}

TABle 2: Particle-size distribution of sand.

\begin{tabular}{lcccccc}
\hline Sieve size $(\mathrm{mm})$ & 4.75 & 2.36 & 1.18 & 0.6 & 0.3 & 0.15 \\
\hline Passing $(\%)$ & 99.74 & 84.81 & 38.20 & 13.96 & 7.06 & 0.00 \\
\hline
\end{tabular}

mineral admixtures on the fluidity, setting time, expansion, strength, and other properties of mortar were studied experimentally. The microstructure of the modified mortar was characterized by X-ray diffraction (XRD), scanning electron microscopy (SEM), and mercury intrusion porosimetry (MIP). Moreover, the expansive performance and strength of the grouting mortar were verified by anchor pullout test.

\section{Materials and Methods}

2.1. Materials. Mineral admixtures (gypsum, bauxite, and alunite) were obtained from Anhui Province in China. The powder size of the mineral admixtures was $80 \mu \mathrm{m}$ after the grinding and sieving. The chemical compositions of these materials are listed in Table 1. CEM I 42.5 cement was used. The phase composition of Portland cement was as follows: $\mathrm{C}_{3} \mathrm{~S}, 56.3 \% ; \mathrm{C}_{2} \mathrm{~S}, 15.5 \% ; \mathrm{C}_{3} \mathrm{~A}, 10.5 \% ; \mathrm{C}_{4} \mathrm{AF}, 7.1 \%$. Figure 1 shows the XRD patterns of gypsum, bauxite, and alunite.

Manufactured sand was used; the cement-to-sand ratio of the mortar was 1:1. The fineness modulus of sand was 3.5 , and the particle-size distribution of the sand is listed in Table 2. Naphthalene series superplasticizer was obtained from Jiangsu Bote New Materials Co., Ltd.

2.2. Physical Properties. The physical properties of grouting mortar mainly refer to the fluidity, setting time, and vertical expansion rate. The fluidity of grouting mortar was measured according to the GB/T 2419-2005 standard [17]. The circular truncated cone die was made of metals with a top inside diameter of $100 \pm 0.5 \mathrm{~mm}$, a bottom inside diameter of $70 \pm 0.5 \mathrm{~mm}$, and the height of $60 \pm 0.5 \mathrm{~mm}$. The setting time of grouting mortar was measured according to the GB/T1346-2011 standard [18]. The vertical expansion rate of grouting mortar was measured according to the JC/T 3132009 standard [19].

2.3. Strength Test. The strength of grouting mortar was measured according to the GB/T 17671-1999 standard [20]. The size of the specimen was $40 \times 40 \times 160 \mathrm{~mm}$. Compressive strength was measured at ages of $1,3,7,14$, and $28 \mathrm{~d}$ under the standard curing conditions (the temperature of curing box was $20 \pm 1^{\circ} \mathrm{C}$, and the relative humidity was $>90 \%$ ).

2.4. Microstructure Analysis. According to the requirement of the analysis, hardened mortar pastes of different ages and proportions were prepared. The samples were immersed in anhydrous ethanol $(99.7 \%)$ to terminate hydration immediately after obtaining the samples. The crystal type, microstructure, and pore size distribution of the samples were analyzed by XRD, SEM, and MIP, respectively.

2.5. Anchor Pullout Test. The ultimate pullout force of the anchor was measured by the laboratory simulation of anchor pullout test. A seamless steel pipe with a length of $1000 \mathrm{~mm}$, an inner diameter of $50 \mathrm{~mm}$, and a wall thickness of $4 \mathrm{~mm}$ was used instead of an external rock soil mass. After the mortar grouting, the pipe was cured at a temperature of $10-15^{\circ} \mathrm{C}$ for $14 \mathrm{~d}$. A computer-controlled Steel Twist Thread Tensile Testing Machine (WYGJ) was used as the test equipment, and the maximum load was $600 \mathrm{kN}$. The stepwise loading method was used. The loading tension per level was set at $\sim 10 \%$ of the ultimate bearing capacity of anchor.

\section{Results}

The fluidity of a grouting mortar is a precondition ensuring the construction quality of an anchor. Grouting mortar with a good fluidity can fulfill the anchor holes without vibration or vibrating slightly under its own gravity. When the initial fluidity is $>260 \mathrm{~mm}$, the grouting mortar has good fluidity. A mortar still has liquidity if 30 min fluidity retention value is $>230 \mathrm{~mm}$.

The test showed that the setting time shortened significantly after alunite was added to the mortar. In particular, when the addition exceeded 5\%, the final setting time was $<30 \mathrm{~min}$. The grouting mortar even condensed during the mixing, thus losing the fluidity. It does not meet the requirements of grouting mortar fluidity. Therefore, the gypsum-bauxite series of mortar was mainly investigated. A superplasticizer can improve the fluidity of grouting mortar effectively. The ratio test showed that the mortar fluidity was the best when the content of naphthalene series superplasticizer was $0.8 \%$. In this study, $0.8 \%$ of naphthalene series superplasticizer was added to both common grouting mortar and gypsum-bauxite grouting mortar.

3.1. Fluidity of Gypsum-Bauxite Grouting Mortar. The main factors affecting the fluidity of gypsum-bauxite grouting mortar are the gypsum content, bauxite content, and water-tobinder ratio. Tests were carried out by orthogonal experiment method. The gypsum contents were $2 \%, 4 \%, 6 \%, 8 \%$, and $10 \%$. The bauxite contents were the same as the gypsum contents. The water-to-binder ratios were $0.28,0.3,0.32,0.34$, and 0.36 . Table 3 shows the orthogonal factor level table. 


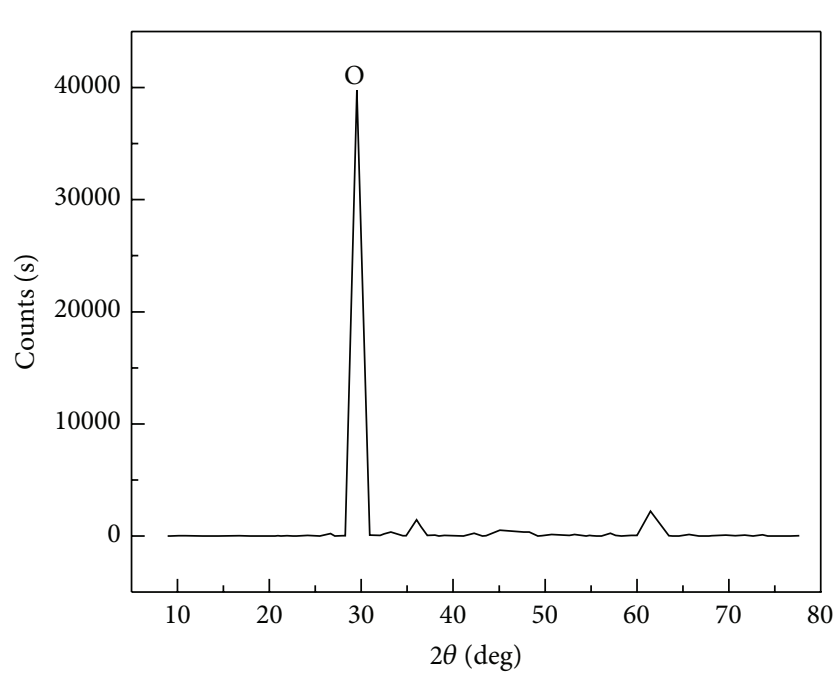

$\mathrm{O} \mathrm{CaSO}_{4}$

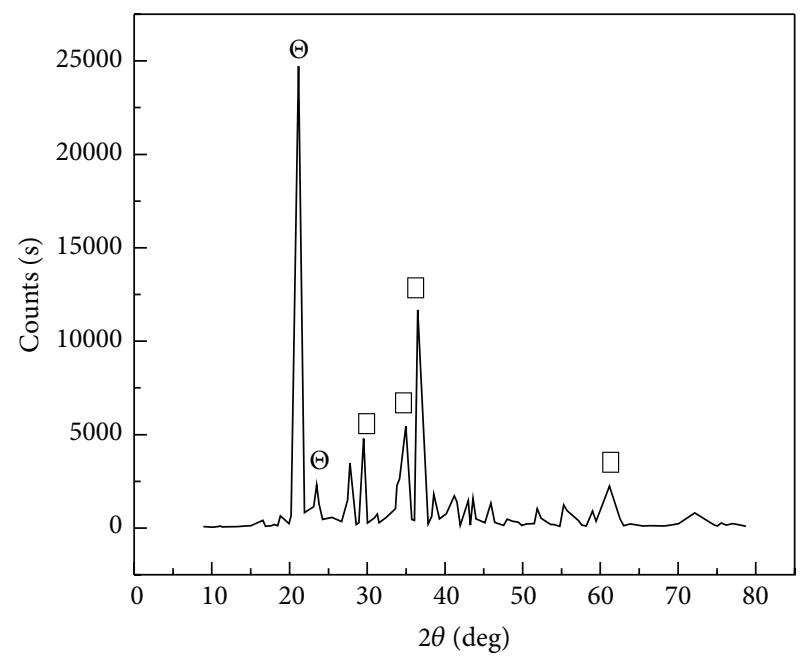

$\Theta \mathrm{Al}(\mathrm{OH})_{3}$

(a) Gypsum

(b) Bauxite

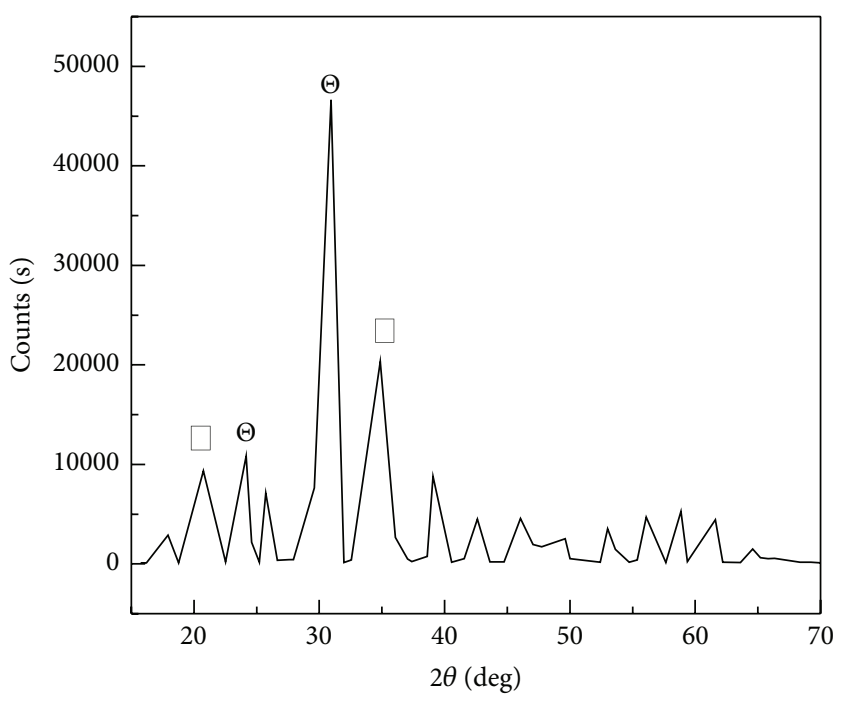

$\Theta \mathrm{SiO}_{2}$

$\square \mathrm{KAl}_{3}\left(\mathrm{SO}_{4}\right)_{2}(\mathrm{OH})_{6}$

(c) Alunite

FIGURE 1: XRD patterns of mineral admixtures.

A total of 25 sets of orthogonal experiments were designed, and the range analysis method was used to analyze the orthogonal experiment results. Table 4 shows the orthogonal experimental results, and Table 5 shows the range analysis results.

The results show that the factors affecting the initial fluidity in a descending order are water-to-binder ratio, bauxite content, and gypsum content. Water-to-binder ratio is the key factor, bauxite content is the important factor, and gypsum content is the general factor. The effects on 30 min fluidity in a descending order are water-to-binder ratio, bauxite content, and gypsum content. However, the difference between the range of bauxite and water-to-binder ratio is slight. Therefore, bauxite content and water-to-binder ratio are the key factors,
TABLE 3: Orthogonal factor level table.

\begin{tabular}{lccc}
\hline Factor & $\begin{array}{c}\text { Gypsum } \\
\text { content }(A)\end{array}$ & $\begin{array}{c}\text { Experiment level } \\
\text { Bauxite } \\
\text { content }(B)\end{array}$ & $\begin{array}{c}\text { Water-to-binder } \\
\text { ratio }(C)\end{array}$ \\
\hline 1 & $2 \%$ & $2 \%$ & 0.28 \\
2 & $4 \%$ & $4 \%$ & 0.30 \\
3 & $6 \%$ & $6 \%$ & 0.32 \\
4 & $8 \%$ & $8 \%$ & 0.34 \\
5 & $10 \%$ & $10 \%$ & 0.36 \\
\hline
\end{tabular}

and gypsum content is the general factor. According to the results of fluidity, water-to-binder ratio should be controlled at $\sim 0.3$ to obtain a good fluidity. If the water-to-binder ratio is 
TABLE 4: Orthogonal experimental results.

\begin{tabular}{|c|c|c|c|c|c|}
\hline No. & $A$ & $B$ & $C$ & $3 \mathrm{~min}$ & $30 \mathrm{~min}$ \\
\hline 1 & 1 & 1 & 2 & 300 & 275 \\
\hline 2 (bleeding) & 2 & 1 & 5 & 345 & 315 \\
\hline 3 (bleeding) & 3 & 1 & 4 & 340 & 310 \\
\hline 4 & 4 & 1 & 1 & 265 & 225 \\
\hline 5 & 5 & 1 & 3 & 315 & 295 \\
\hline 6 & 1 & 2 & 3 & 325 & 285 \\
\hline 7 & 2 & 2 & 2 & 290 & 260 \\
\hline 8 (bleeding) & 3 & 2 & 5 & 340 & 293 \\
\hline 9 (bleeding) & 4 & 2 & 4 & 340 & 295 \\
\hline 10 & 5 & 2 & 1 & 200 & 170 \\
\hline 11 & 1 & 3 & 1 & 235 & 190 \\
\hline 12 & 2 & 3 & 3 & 315 & 275 \\
\hline 13 & 3 & 3 & 2 & 275 & 245 \\
\hline 14 & 4 & 3 & 5 & 335 & 285 \\
\hline 15 & 5 & 3 & 4 & 310 & 275 \\
\hline 16 & 1 & 4 & 4 & 330 & 260 \\
\hline 17 & 2 & 4 & 1 & 215 & 165 \\
\hline 18 & 3 & 4 & 3 & 285 & 235 \\
\hline 19 & 4 & 4 & 2 & 262 & 230 \\
\hline 20 & 5 & 4 & 5 & 335 & 280 \\
\hline 21 & 1 & 5 & 5 & 330 & 235 \\
\hline 22 & 2 & 5 & 4 & 290 & 215 \\
\hline 23 & 3 & 5 & 1 & 180 & 120 \\
\hline 24 & 4 & 5 & 3 & 255 & 195 \\
\hline 25 & 5 & 5 & 2 & 230 & 165 \\
\hline
\end{tabular}

TABLE 5: Range analysis results.

\begin{tabular}{ccccccc}
\hline & \multicolumn{2}{c}{ Gypsum content } & \multicolumn{2}{c}{ Bauxite content } & \multicolumn{2}{c}{ Water-to-binder ratio } \\
& $3 \mathrm{~min}$ & $30 \mathrm{~min}$ & $3 \mathrm{~min}$ & $30 \mathrm{~min}$ & $3 \mathrm{~min}$ & $30 \mathrm{~min}$ \\
\hline Range & 130 & 60 & 280 & 490 & 590 & 538 \\
\hline
\end{tabular}

too large, bleeding and segregation will occur. Conversely, it is difficult to meet the construction requirements if the waterto-binder ratio is too small. By adding mineral admixtures, the fluidity of a grouting mortar can be affected by changing the speed of the hydration reaction, particularly the fluidity retention value for $30 \mathrm{~min}$.

3.2. Setting Time of Gypsum-Bauxite Grouting Mortar. To study the effect of gypsum and bauxite on the setting time of grouting mortar, three different amounts were selected to perform the contrast experiment. The results are listed in Table 6.

As shown in Table 6, the setting time of grouting mortar increased after the addition of gypsum. Conversely, the setting time decreased after the addition of bauxite, and the decrease was larger. The addition of gypsum increased the previous concentration of $\mathrm{SO}_{4}{ }^{2-}$, which reacted with the cement hydration products and generated ettringite. Ettringite covered the surface of cement clinker particles to form a compact film, thus hindering further hydration of cement particles. Gypsum shows a significant retarding effect. Bauxite contains more active ingredients such as $\mathrm{Al}_{2} \mathrm{O}_{3}$ which reacts with $\mathrm{Ca}(\mathrm{OH})_{2}$ in water to generate hydrated calcium aluminate. Simultaneously, $\mathrm{Ca}(\mathrm{OH})_{2}$ in the hydration products of cement clinker is consumed, and the hydration reaction is promoted. Bauxite shows a significant coagulating effect.

The content of mineral admixture and molar ratio $K(K=$ $\mathrm{SO}_{3} / \mathrm{Al}_{2} \mathrm{O}_{3}$ ) significantly affected the setting time of grouting mortar. The total content of mineral admixture and value of $K$ were adjusted to perform the contrast experiment. The waterto-binder ratio was 0.3 . The results are shown in Table 7.

As shown in Table 7, both the initial and final setting times of grouting mortar decreased with the increase in the total content of mineral admixture. To meet the requirements of the fluidity of grouting mortar, the total content of mineral admixture should be controlled within $15 \%$. When $K$ is 1 , the setting time decreased significantly. The reduction is more prominent than that when $K$ is 3 . In the hydration reaction, the theoretical value of $K$ is 3 . If $K<3$, bauxite is still surplus after gypsum is completely consumed by the reaction; that is, the amount of gypsum is insufficient. When $K$ changed from 1 to 3 , the content of gypsum increased, thus increasing the retarding action of gypsum with the increase in the setting time. The results show that the total content of mineral admixture should be controlled within $15 \%$ to obtain a better setting time. Moreover, the setting time of grouting mortar was the shortest when $K$ was 1 .

3.3. Expansive Performance of Gypsum-Bauxite Grouting Mortar. Gypsum and bauxite significantly affected the expansive performance of grouting mortar. Expansive performance tests were carried out by adding different amounts of gypsum or bauxite to grouting mortar. The results are shown in Figures 2 and 3.

Figure 2 shows that the vertical expansion rate increased after the hardening of grouting mortar with the increase in gypsum content. The vertical volume expansion rate reached $0.05 \%$ when the gypsum content was $9 \%$. Moreover, the gypsum content affected the stability time of the expansion. When the content was $3 \%$, the stability time is at $\sim 10 \mathrm{~d}$. When the content was $9 \%$, a certain degree of vertical expansion growth was observed. The greater the gypsum content, the longer the volume stability time. The addition of gypsum provided a large amount of $\mathrm{SO}_{4}{ }^{2-}$ for the hydration reaction, thus affecting the yield and speed of ettringite directly. In a macroscopic view, this indicates the value of the expansion ratio and the length of the volume stability time.

Figure 3 shows that the change in vertical expansion rate is not clear after the hardening of grouting mortar with the addition of bauxite. The late vertical expansion rate changed slightly, particularly when the bauxite content was $>4 \%$. This is because the addition of bauxite accelerated the speed of hydration reaction, thus affecting the production speed of ettringite, but not the yields. When the amount of gypsum was insufficient, ettringite reacted with the cement hydration products and generated monosulfoaluminate (AFm, $3 \mathrm{CaO} \cdot \mathrm{Al}_{2} \mathrm{O}_{3} \cdot \mathrm{CaSO}_{4} \cdot 12 \mathrm{H}_{2} \mathrm{O}$ ), which does not expand the volume. Therefore, the late vertical expansion rate was basically the same when the bauxite contents were $4 \%$ and $6 \%$. 
TABLE 6: Effect of gypsum and bauxite on the setting time of grouting mortar.

\begin{tabular}{lccccc}
\hline \multirow{2}{*}{ Number } & Mortar $(\mathrm{g})$ & Gypsum $(\mathrm{g})$ & Bauxite $(\mathrm{g})$ & Initial setting time $(\mathrm{min})$ & Final setting time $(\mathrm{min})$ \\
\hline 1 & 1400 & 0 & 0 & 215 & 301 \\
2 & 1400 & 117 & 0 & 251 & 357 \\
3 & 1400 & 0 & 48.6 & 55 & 86 \\
\hline
\end{tabular}

TABLE 7: Effect of mineral content and molar ratio $K$ on setting time of grouting mortar.

\begin{tabular}{|c|c|c|c|c|c|c|c|c|}
\hline \multirow{2}{*}{\multicolumn{2}{|c|}{ Number Mortar (g) }} & \multirow{3}{*}{$\begin{array}{c}\text { Total content }(\%) \\
5\end{array}$} & \multirow{3}{*}{$\begin{array}{c}\text { Water }(\mathrm{mL}) \\
236.3\end{array}$} & \multirow{3}{*}{$\begin{array}{c}\text { Cement content (\%) } \\
41.0\end{array}$} & \multicolumn{2}{|c|}{$K=3$} & \multicolumn{2}{|c|}{$K=1$} \\
\hline & & & & & $\begin{array}{c}\text { Initial setting } \\
\text { time (min) }\end{array}$ & $\begin{array}{c}\text { Final setting } \\
\text { time (min) }\end{array}$ & $\begin{array}{l}\text { Initial setting } \\
\text { time (min) }\end{array}$ & $\begin{array}{c}\text { Final setting } \\
\text { time (min) }\end{array}$ \\
\hline 1 & 1500 & & & & 130 & 175 & 90 & 153 \\
\hline 2 & 1500 & 7.5 & 241.9 & 39.8 & 93 & 164 & 70 & 135 \\
\hline 3 & 1500 & 10 & 247.5 & 38.6 & 67 & 124 & 67 & 119 \\
\hline 4 & 1500 & 12.5 & 253.1 & 37.4 & 54 & 112 & 41 & 76 \\
\hline 5 & 1500 & 15 & 258.8 & 36.2 & 46 & 86 & 31 & 57 \\
\hline 6 & 1500 & 17.5 & 264.4 & 35.1 & 46 & 78 & 27 & 53 \\
\hline 7 & 1500 & 20 & 270.0 & 33.9 & 36 & 66 & 25 & 48 \\
\hline
\end{tabular}

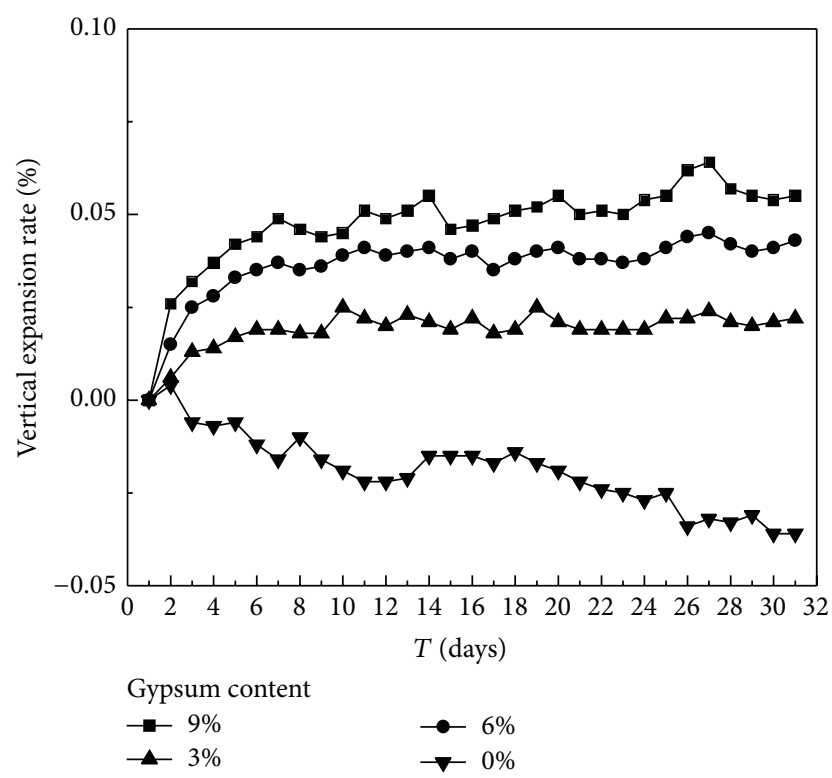

Figure 2: Effect of gypsum content on expansion rate.

The content of mineral admixture and molar ratio $K(K=$ $\mathrm{SO}_{3} / \mathrm{Al}_{2} \mathrm{O}_{3}$ ) significantly affected the vertical expansion rate of grouting mortar. The total content of mineral admixture and value of $K$ were adjusted to perform the contrast experiment. The water-to-binder ratio was 0.3 . The results are shown in Figures 4 and 5.

Figures 4 and 5 show that the vertical expansion rate increased after the hardening of grouting mortar with the increase in the total content of mineral admixture. When the molar ratio $K$ increased from 1 to 3 , not only the vertical expansion rate increased, but also the amount of expansion increased clearly under the same total content condition.

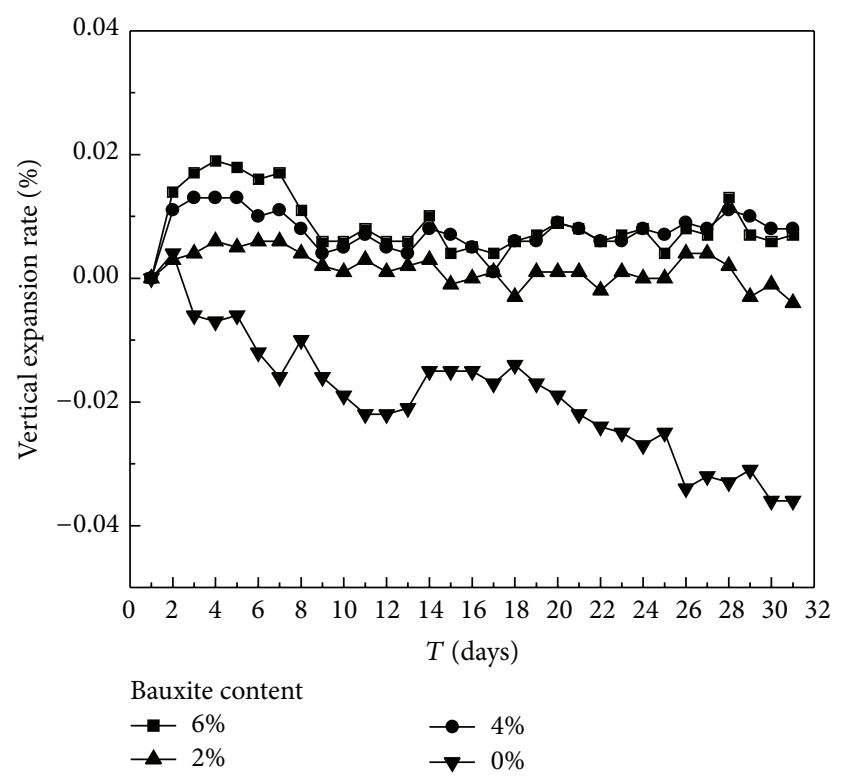

FIGURE 3: Effect of bauxite content on expansion rate.

When $K$ is 1 , the amount of gypsum is insufficient. Ettringite continues to react with the cement hydration products and generates AFm which does not expand the volume. Therefore, the change in vertical expansion rate was not obvious with the increase in the total content of mineral admixture. When $K$ is 3 , the amount of gypsum is sufficient for the hydration reaction. Ettringite can be generated stably. The results show that the total content of mineral admixture should be controlled at $\sim 15 \%$, in which case, the hardened mortar has a good expansion amount in the early days and the late expansion has a better stability. Moreover, the grouting mortar exhibited the best expansive performance when $K$ was 3. 
TABLE 8: Mineral content and setting time of gypsum-bauxite grouting mortar.

\begin{tabular}{|c|c|c|c|c|c|c|c|c|}
\hline & $\begin{array}{l}\text { Mortar } \\
(\mathrm{g})\end{array}$ & $\begin{array}{c}\text { Gypsum } \\
(\mathrm{g})\end{array}$ & $\begin{array}{c}\text { Bauxite } \\
(\mathrm{g})\end{array}$ & $\begin{array}{c}\text { Total content/ } \\
\%\end{array}$ & $K$ & $\begin{array}{c}\text { Cement } \\
\text { content (\%) }\end{array}$ & $\begin{array}{l}\text { Initial setting } \\
\text { time (min) }\end{array}$ & $\begin{array}{l}\text { Final setting } \\
\text { time (min) }\end{array}$ \\
\hline Common mortar & 1400 & 0 & 0 & 0 & I & 43.4 & 245 & 301 \\
\hline A1 & 1400 & 117 & 59.7 & 12.6 & 2.5 & 37.4 & 66 & 113 \\
\hline $\mathrm{A} 2$ & 1400 & 117 & 74.6 & 13.7 & 2 & 36.9 & 51 & 75 \\
\hline
\end{tabular}

TABLE 9: Strength of gypsum-bauxite grouting mortar.

\begin{tabular}{|c|c|c|c|c|c|c|c|c|c|c|}
\hline & \multicolumn{5}{|c|}{ Flexural strength $(\mathrm{MPa})$} & \multicolumn{5}{|c|}{ Compressive strength (MPa) } \\
\hline & $1 \mathrm{~d}$ & $3 \mathrm{~d}$ & $7 \mathrm{~d}$ & $14 \mathrm{~d}$ & $28 \mathrm{~d}$ & $1 \mathrm{~d}$ & $3 \mathrm{~d}$ & $7 \mathrm{~d}$ & $14 \mathrm{~d}$ & $28 \mathrm{~d}$ \\
\hline Common mortar & 4.1 & 7.95 & 8.31 & 8.95 & 9.48 & 15.5 & 37.3 & 50.9 & 60.1 & 64.4 \\
\hline $\mathrm{A} 1$ & 4.17 & 6.06 & 6.65 & 7.3 & 9.4 & 16.6 & 34.5 & 46.9 & 61.5 & 63.1 \\
\hline $\mathrm{A} 2$ & 3.84 & 5.92 & 7.42 & 8.29 & 9.9 & 14.3 & 34.6 & 44.3 & 59.3 & 68.1 \\
\hline
\end{tabular}

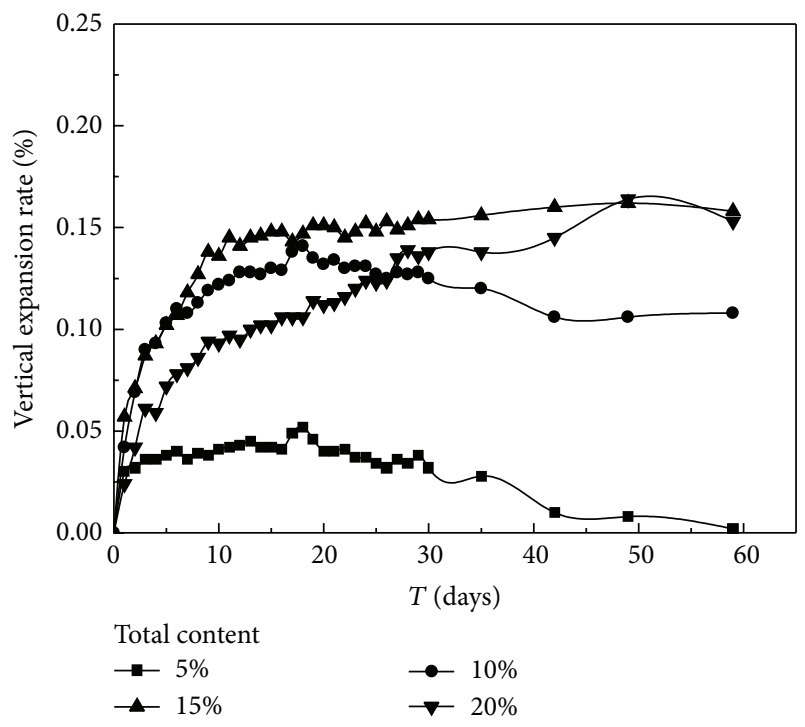

FIGURE 4: Effect of the total content on expansion rate $(K=1)$.

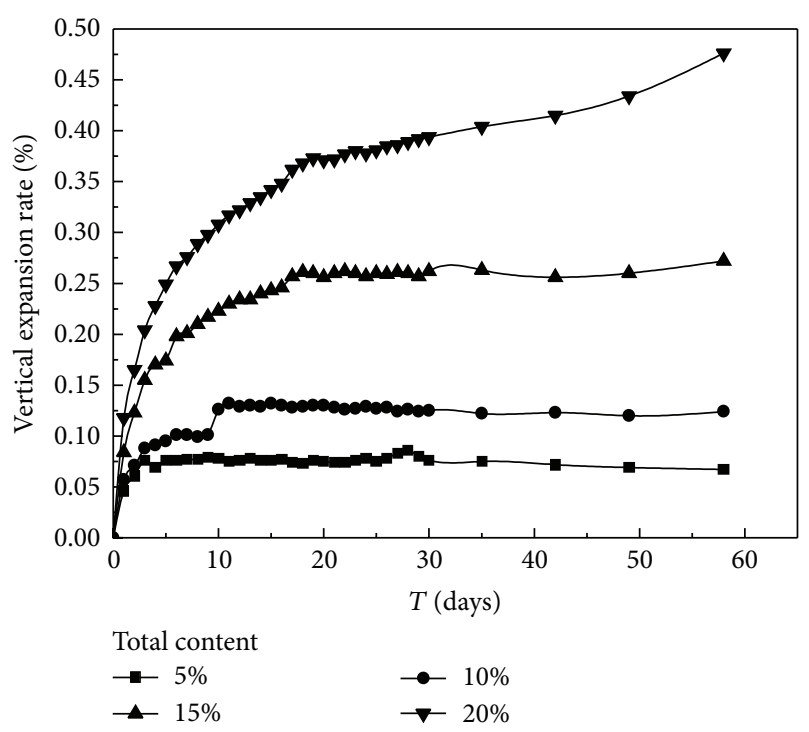

FIGURE 5: Effect of the total content on expansion rate $(K=3)$.
3.4. Strength of Gypsum-Bauxite Grouting Mortar. According to the test results of fluidity, setting time, and expansion, the water-to-binder ratio of gypsum-bauxite grouting mortar should be 0.3 , and the content of mineral admixture should be controlled at $\sim 15 \%$. Considering the effects on setting time and expansive performance, the molar ratio $K$ was maintained between 2 and 2.5. The strength tests were carried out according to the data shown in Table 8 . The results of fluidity tests show that two groups of specimens met the requirements of fluidity. The results of expansive performance tests show that vertical expansion rate of the two groups of samples was stabilized at $\sim 0.2 \%$.

For the two groups of gypsum-bauxite grouting mortar samples, strength tests were carried out according to the data shown in Table 8, and the results were compared to those of the common grouting mortar. The results are shown in Table 9.

Table 9 shows that the compressive strengths of 1 and $3 \mathrm{~d}$ are approximately $14 \mathrm{MPa}$ and $34 \mathrm{MPa}$, respectively. The compressive strength of $28 \mathrm{~d}$ is $>60 \mathrm{MPa}$. The compressive strength of $3 \mathrm{~d}$ is $50 \%$ higher than that of $28 \mathrm{~d}$. Thus, the gypsum-bauxite grouting mortar has the characteristics of early strength and high strength. The addition of gypsum and bauxite slightly affected the strength of the mortar. The early strength is slightly lower, and the latter strength is almost the same as that of the common mortar. Next, the microstructure analysis of gypsum-bauxite grouting mortar is reported.

3.5. Microstructure Analysis. The XRD pattern was analyzed using A2 as an example. The results are shown in Figure 6.

Figure 6 shows that the amount of gypsum and bauxite in the hardened pastes decreased rapidly with aging, participating in the hydration reaction of cement clinker. Moreover, with aging, the amount of ettringite (AFt) increased. In general, the strength value of gypsum-bauxite grouting mortar increases continually with the increase in the hydration products.

The SEM results of the gypsum-bauxite grouting mortar (A2 sample) are shown in Figure 7.

Figure 7 shows a large number of thin sheets of calcium hydroxide $\left(\mathrm{Ca}(\mathrm{OH})_{2}\right)$ at $3 \mathrm{~d}$, filling a large amount of hydration products such as ettringite in the pores. However, the porosity is not high on the whole. At $28 \mathrm{~d}$, several columnar 

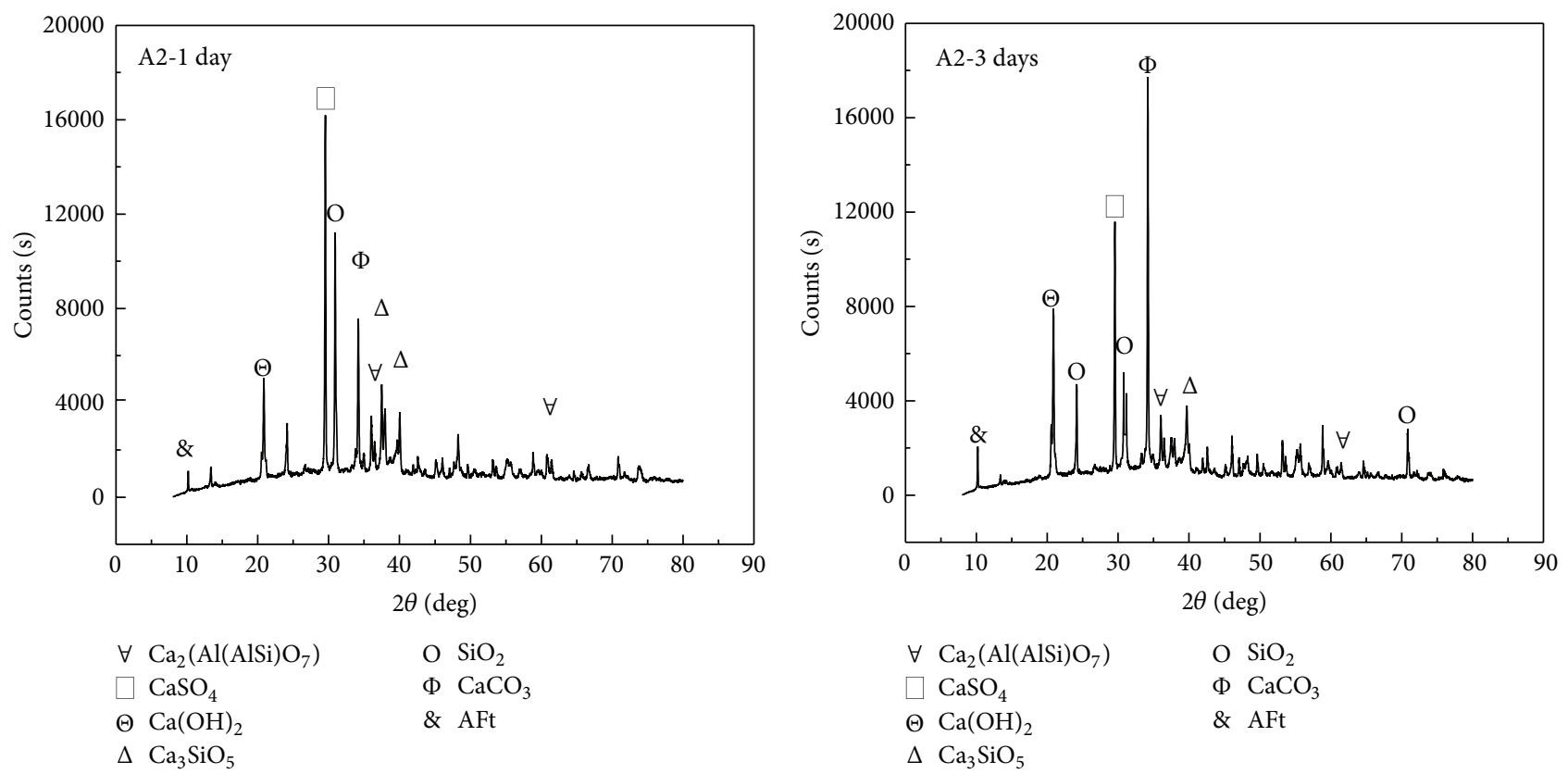

(a) $1 \mathrm{~d}$

(b) $3 \mathrm{~d}$

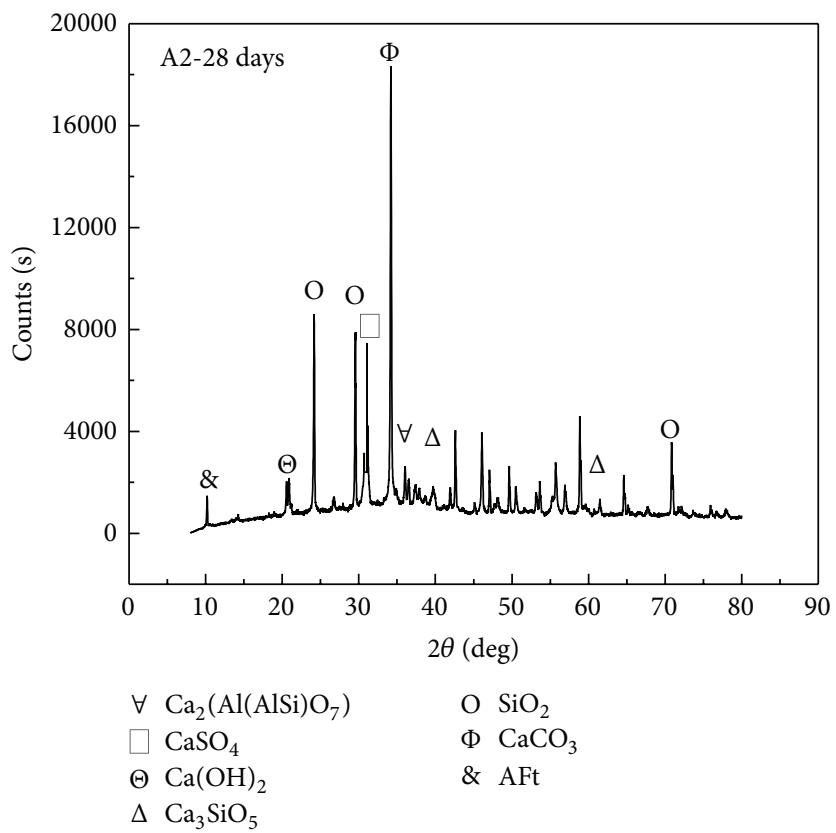

(c) $28 \mathrm{~d}$

FIGURE 6: XRD patterns of gypsum-bauxite grouting mortar.

and acicular ettringite were observed, overlapping each other intricately to form a relatively complete skeletal system. This contributes significantly to the strength of hardened paste, affecting the latter strength obviously.

The strength of a mortar has a close relationship with the size and number of pores. The pore diameter distribution of gypsum-bauxite grouting mortar (A2 sample) was analyzed by MIP and compared to that of the common grouting mortar. The results are shown in Figure 8.
Figure 8 shows that the pore diameter of the common mortar is mainly $>100 \mu \mathrm{m}$, whereas the pore diameter of gypsum-bauxite grouting mortar (A2 sample) is between 10 and $100 \mu \mathrm{m}$ at $28 \mathrm{~d}$. Simultaneously, the pore structure results show that the total porosity of the common mortar was $3.49 \%$, whereas that of the gypsum-bauxite grouting mortar (A2 sample) was $1.84 \%$ at $28 \mathrm{~d}$. Thus, the total porosity significantly reduced, clearly indicating the effect of mineral admixture and the improvement in strength. 


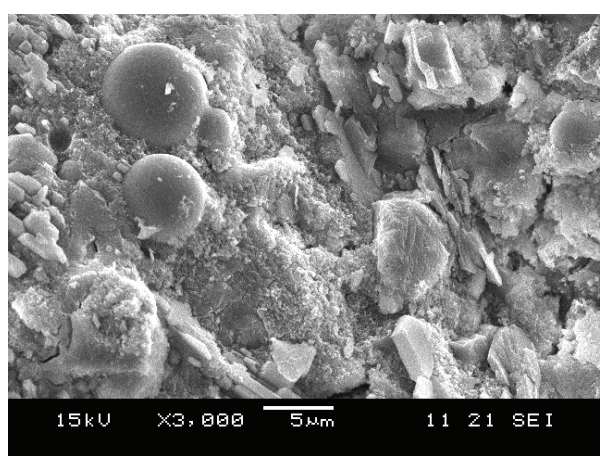

(a) $3 \mathrm{~d}$

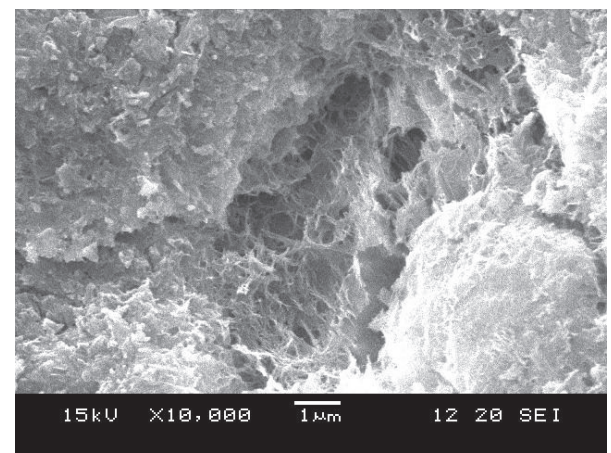

(b) $28 \mathrm{~d}$

FIGURE 7: SEM images of gypsum-bauxite grouting mortar.
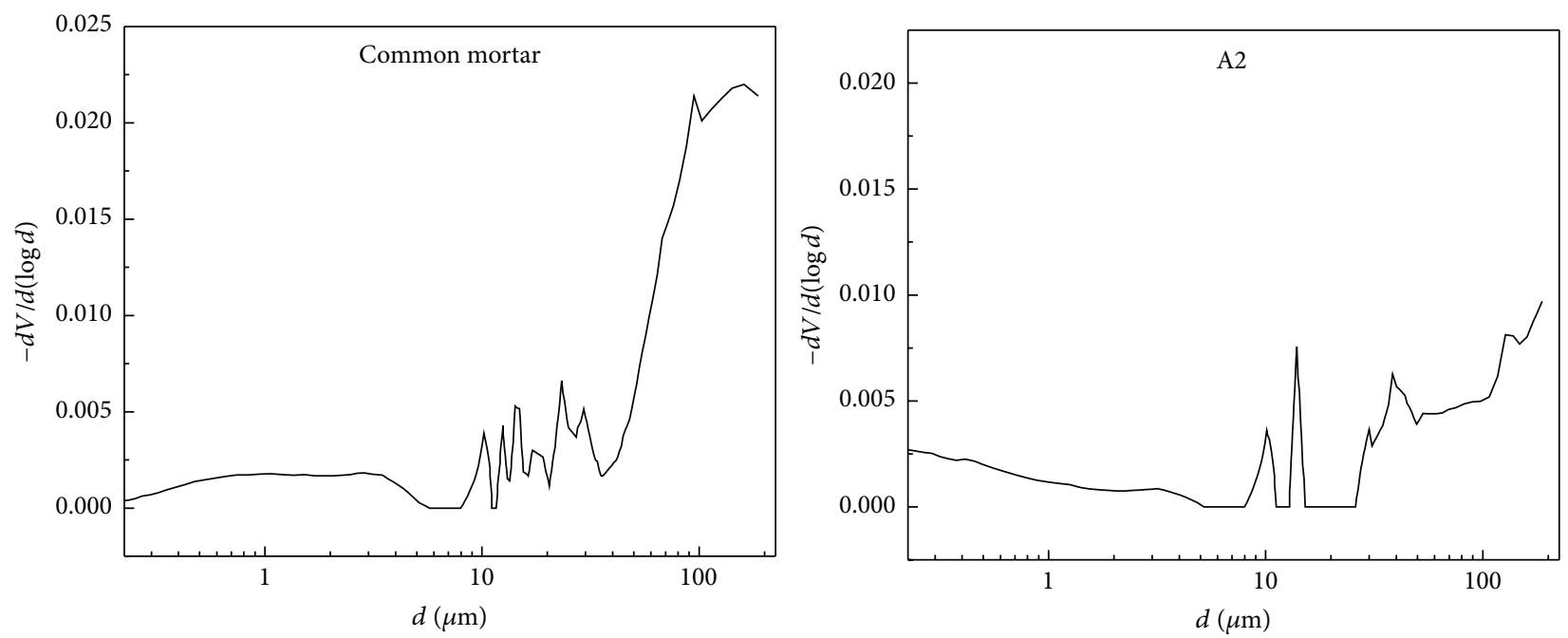

FIgURE 8: Pore diameter distribution of hardened pastes $(T=28 \mathrm{~d})$.

The above tests show that the gypsum-bauxite grouting mortar (A2 sample) has the following properties. (1) Good fluidity: the initial fluidity is $>260 \mathrm{~mm}$, and the 30 min fluidity retention value is $>230 \mathrm{~mm}$. (2) Short setting time: the initial setting time is controlled at $\sim 1 \mathrm{~h}$, and the final setting time is controlled within $2 \mathrm{~h}$. (3) Expansive performance: the hardened mortar has a good expansion amount in the early days, and the late expansion is stabilized at $\sim 0.2 \%$. (4) Early strength and high strength: the compressive strengths of $1 \mathrm{~d}$ and $3 \mathrm{~d}$ are approximately $14 \mathrm{MPa}$ and $34 \mathrm{MPa}$, respectively. The compressive strength of $28 \mathrm{~d}$ is $>60 \mathrm{MPa}$.

3.6. Pullout Force of Anchor. To study the effect of gypsumbauxite grouting mortar on the pullout force of anchor, A2 was used as an example to perform the pullout test of anchor. The pullout test of the common grouting mortar without mineral admixture was conducted for comparison. The results are shown in Figure 9. The damage of anchor is shown in Figure 10.

Figure 9 shows that the ultimate bearing capacity of a $1 \mathrm{~m}$ long simulation anchor for A2 sample is $74 \mathrm{kN}$, whereas that of a $1 \mathrm{~m}$ long simulation anchor using the common grouting mortar is only $53 \mathrm{kN}$. The ultimate bearing capacity increased by $39.6 \%$. Both the load-displacement curves are relatively flat with a smaller slope, and the pullout force increased slowly.

The anchor forces mainly comprise the cohesion and friction between anchorage body and rock; therefore, the strength of anchoring material can directly affect the anchor force [21]. Moreover, the modest expansion significantly benefits the anchor force. When the anchor is damaged, the anchorage body is pulled out from the pipe, and the mortar remains intact. The results show that the strength of the mortar is good, and the anchor damage occurred between the anchorage body and steel tube wall. The anchor failed because the cohesion and friction between anchorage body and steel tube wall are less than that of the anchor tension. Because of the addition of gypsum and bauxite, the mortar had modest volume expansion, thus increasing the stress between anchoring body and steel tube wall. The cohesion and friction were better than those of the ordinary grouting material. Therefore, the pullout force of anchor increased. The result shows that the gypsum-bauxite grouting mortar has a higher ultimate bearing capacity than the common mortar. The ultimate bearing capacity increased by $39.6 \%$. 


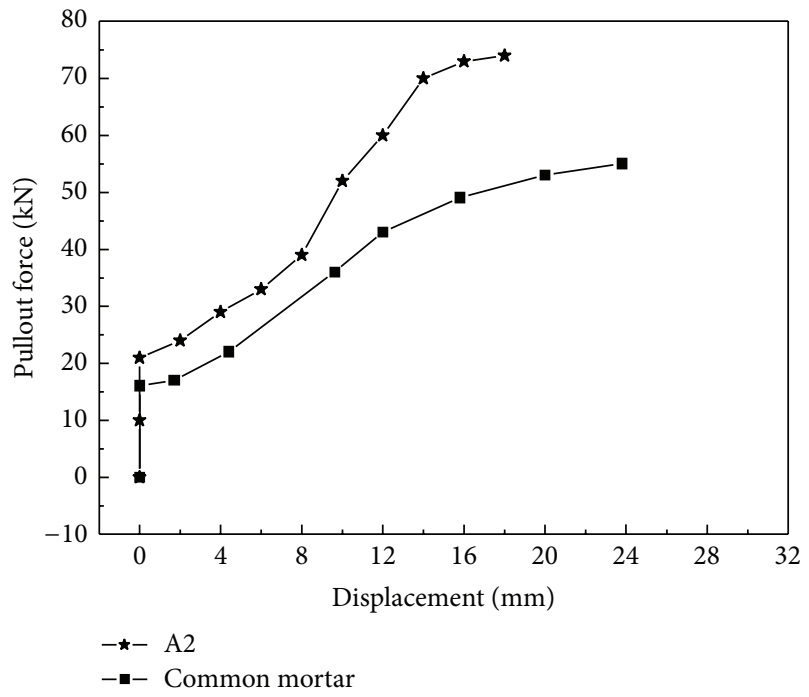

FIGURE 9: Load-displacement curves of pullout tests.

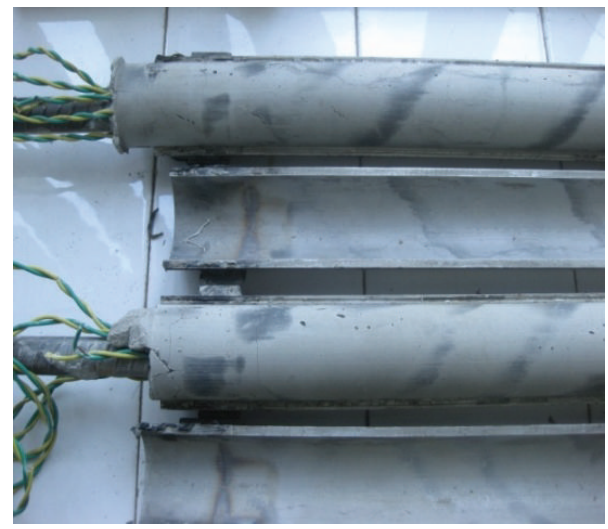

FIGURE 10: Damage of anchor.

\section{Discussion}

The tests revealed that the setting time shortened significantly after alunite was added to the mortar, particularly when the addition exceeded 5\%. The grouting mortar even condensed during the mixing, thus losing the fluidity. This does not meet the requirements of grouting mortar fluidity. This characteristic of alunite makes it possible to use alunite grouting mortar in rapid repair and planting-bar anchorage.

Alunite, $\mathrm{KAl}_{3}\left(\mathrm{SO}_{4}\right)_{2}(\mathrm{OH})_{6}$ is not soluble in water in its original form. Alunite additive cements harden rapidly and have high strength, because alunite is used as an accelerator in cement production [22]. When alunite is added to Portland cement, the hardening time decreases, while the expansion increases. It is also possible to achieve concrete with a high early strength by adding alunite to cement [23]. However, alunite mortar has been rarely studied. Katsioti et al. [24] studied the utilization of jarosite/alunite residue for the restoration of mortars, and the jarosite/alunite residue improved the mechanical behavior of the resulting mortars. In this section,
TABLE 10: Effect of alunite on the setting time of grouting mortar.

\begin{tabular}{lccccc}
\hline Number & $\begin{array}{c}\text { Mortar } \\
(\mathrm{g})\end{array}$ & $\begin{array}{c}\text { Content } \\
(\%)\end{array}$ & $\begin{array}{c}\text { Alunite } \\
(\mathrm{g})\end{array}$ & $\begin{array}{c}\text { Initial setting } \\
\text { time }(\mathrm{min})\end{array}$ & $\begin{array}{c}\text { Final setting } \\
\text { time }(\mathrm{min})\end{array}$ \\
\hline $\mathrm{K} 1$ & 1400 & 3.6 & 50 & 42 & 92 \\
$\mathrm{~K} 2$ & 1400 & 7.1 & 100 & 6 & 26 \\
$\mathrm{~K} 3$ & 1400 & 14.2 & 200 & 4 & 8 \\
\hline
\end{tabular}

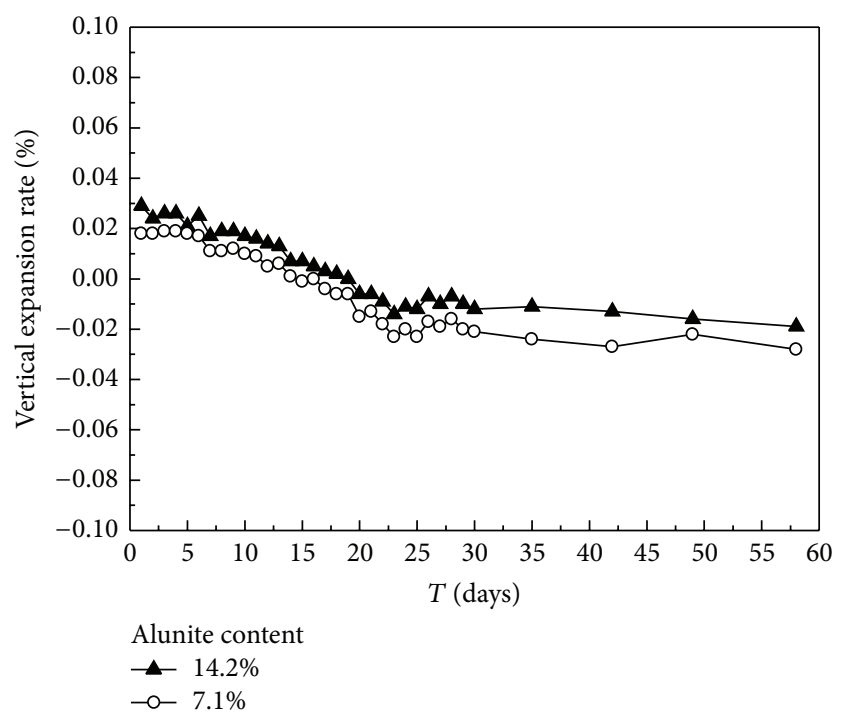

FIGURE 11: Effect of alunite content on expansion rate.

the effects of alunite content on the setting time, expansion, and strength of grouting mortar are reported.

To study the effect of alunite on the setting time of grouting mortar, three different amounts were selected to perform the contrast experiment. The water-to-binder ratio was 0.3 , and the naphthalene series superplasticizer was not used. The results are shown in Table 10.

As shown in Table 10, both the initial and final setting times of grouting mortar reduced significantly with the increase in the alunite content. Alunite provides both $\mathrm{Al}^{3+}$ and $\mathrm{SO}_{4}{ }^{2-}$ for the hydration reaction, thus rapidly producing large amounts of ettringite and promoting the rapid condensation of mortar. To study the effect of alunite on the expansive performance of mortar, expansive performance tests (K2 and K3) were conducted. The results are shown in Figure 11 .

Figure 11 shows that the hardened mortar underwent a certain volume expansion with the addition of alunite in the early days. The vertical expansion rate increased with the increase in alunite content. However, the hardened mortar shrank after $15 \mathrm{~d}$. Alunite provides both $\mathrm{Al}_{2} \mathrm{O}_{3}$ and $\mathrm{SO}_{3}$ for the hydration reaction, thus rapidly producing large amounts of ettringite in the early days. Therefore, the hardened mortar had a certain volume expansion. However, the hydration reaction consumes large amounts of water simultaneously, and the value of $\mathrm{SO}_{3} / \mathrm{Al}_{2} \mathrm{O}_{3}$ is $\sim 1$ in alunite. The amount of $\mathrm{SO}_{3}$ is relatively insufficient, and the ettringite continues to react with the cement hydration products and generates AFm 
which cannot expand the volume. Therefore, the hardened mortar shrank after $15 \mathrm{~d}$.

The strength tests were carried out using $\mathrm{K} 2$ as an example. The results show that alunite mortar has obvious characteristics of early strength. The compressive strengths of $0.5,1$, and $3 \mathrm{~d}$ are approximately $14.8 \mathrm{MPa}, 26.6 \mathrm{Mpa}$, and 41.1 $\mathrm{MPa}$, respectively.

In summary, alunite mortar has the following characteristics: very short setting time, early volume expansion, and significant early strength. Therefore, alunite mortar can be used in rapid repair and planting-bar anchorage.

\section{Conclusions}

In this study, a gypsum-bauxite high-performance grouting mortar was developed. The mortar has the following properties. (1) Good fluidity: the initial fluidity value is $>260 \mathrm{~mm}$, and the $30 \mathrm{~min}$ fluidity retention value is $>230 \mathrm{~mm}$. (2) Short setting time: the initial setting time is controlled at $\sim 1 \mathrm{~h}$, and the final setting time is controlled within $2 \mathrm{~h}$. (3) Expansive performance: the hardened mortar has a good expansion amount in the early days, and late expansion is stabilized at $\sim 0.2 \%$. (4) Early strength and high strength: the compressive strengths of $1 \mathrm{~d}$ and $3 \mathrm{~d}$ are approximately $14 \mathrm{MPa}$ and $34 \mathrm{MPa}$, respectively. The compressive strength of $28 \mathrm{~d}$ is $>60 \mathrm{MPa}$. The best conditions for gypsum-bauxite grouting mortar are as follows: a water-to-binder ratio is 0.3 , a mineral admixture content of $\sim 15 \%$, and a molar ratio $K$ of 2 .

The expansive performance and strength of the grouting mortar were verified by anchor pullout test. The results show that gypsum-bauxite grouting mortar has a higher ultimate bearing capacity than the common mortar. The ultimate bearing capacity increased by $39.6 \%$. Alunite mortar has the following characteristics: very short setting time, early volume expansion, and significant early strength; thus, it can be used in rapid repair and planting-bar anchorage.

\section{Conflict of Interests}

The authors declare that there is no conflict of interests regarding the publication of this paper.

\section{Acknowledgment}

This work was financially supported by nuclear wastes major project of the State Administration of Science, Technology and Industry for National Defense (SASTIND) (FZ1402-06).

\section{References}

[1] J. J. Assaad and Y. Daou, "Cementitious grouts with adapted rheological properties for injection by vacuum techniques," Cement and Concrete Research, vol. 59, pp. 43-54, 2014.

[2] M. J. Shannag, "High-performance cementitious grouts for structural repair," Cement and Concrete Research, vol. 32, no. 5, pp. 803-808, 2002.

[3] S. Rukzon and P. Chindaprasirt, "Strength, porosity, and chloride resistance of mortar using the combination of two kinds of pozzolanic materials," International Journal of Minerals, Metallurgy and Materials, vol. 20, no. 8, pp. 808-814, 2013.

[4] C. Jaturapitakkul, J. Tangpagasit, S. Songmue, and K. Kiattikomol, "Filler effect of fine particle sand on the compressive strength of mortar," International Journal of Minerals, Metallurgy and Materials, vol. 18, no. 2, pp. 240-246, 2011.

[5] K. H. Khayat, "Viscosity-enhancing admixtures for cementbased materials-an overview," Cement and Concrete Composites, vol. 20, no. 2-3, pp. 171-188, 1998.

[6] M. Şahmaran, N. Özkan, S. B. Keskin, B. Uzal, I. Ö. Yaman, and T. K. Erdem, "Evaluation of natural zeolite as a viscositymodifying agent for cement-based grouts," Cement and Concrete Research, vol. 38, no. 7, pp. 930-937, 2008.

[7] A. Yahia and K. H. Khayat, "Applicability of rheological models to high-performance grouts containing supplementary cementitious materials and viscosity enhancing admixture," Materials and Structures, vol. 36, no. 260, pp. 402-412, 2003.

[8] I. N. Markou and A. I. Droudakis, "Factors affecting engineering properties of microfine cement grouted sands," Geotechnical and Geological Engineering, vol. 31, no. 4, pp. 1041-1058, 2013.

[9] O. S. B. Al-Amoudi, T. O. Abiola, and M. Maslehuddin, "Effect of superplasticizer on plastic shrinkage of plain and silica fume cement concretes," Construction and Building Materials, vol. 20, no. 9, pp. 642-647, 2006.

[10] E. Holt, "Contribution of mixture design to chemical and autogenous shrinkage of concrete at early ages," Cement and Concrete Research, vol. 35, no. 3, pp. 464-472, 2005.

[11] J. M. Khatib and P. S. Mangat, "Influence of superplasticizer and curing on porosity and pore structure of cement paste," Cement and Concrete Composites, vol. 21, no. 5-6, pp. 431-437, 1999.

[12] E. Sakai, T. Kasuga, T. Sugiyama, K. Asaga, and M. Daimon, "Influence of superplasticizers on the hydration of cement and the pore structure of hardened cement," Cement and Concrete Research, vol. 36, no. 11, pp. 2049-2053, 2006.

[13] I. Odler and J. Colán-Subauste, "Investigations on cement expansion associated with ettringite formation," Cement and Concrete Research, vol. 29, no. 5, pp. 731-735, 1999.

[14] K. Tosun and B. Baradan, "Effect of ettringite morphology on DEF-related expansion," Cement and Concrete Composites, vol. 32, no. 4, pp. 271-280, 2010.

[15] H. Bouzabata, S. Multon, A. Sellier, and H. Houari, "Effects of restraint on expansion due to delayed ettringite formation," Cement and Concrete Research, vol. 42, no. 7, pp. 1024-1031, 2012.

[16] W. Nocuń-Wczelik, A. Stok, and Z. Konik, "Heat evolution in hydrating expansive cement systems," Journal of Thermal Analysis and Calorimetry, vol. 101, no. 2, pp. 527-532, 2010.

[17] GB/T 2419-2005, Test Method for Fluidity of Cement Mortar, China Planning Press, Beijing, China, 2005, (Chinese).

[18] GB/T 1346-2011 Test Methods for Water Requirement of Normal Consistency, Setting Time and Soundness of the Portland Cement, China Planning Press, Beijing, China, 2011, (Chinese).

[19] JC/T 313-2009, Test Method for Determining Expansive Ratio of Expansive Cement, China Building Material Industry Publishing House, Beijing, China, 2010, (Chinese).

[20] CNS, "Method of testing cements-determination of strength," Chinese Standard GB/T 17671-1999, China Planning Press, Beijing, China, 1999, (Chinese).

[21] R. Widmann, R. Steiger, and E. Gehri, "Pull-out strength of axially loaded steel rods bonded in glulam perpendicular to the grain," Materials and Structures, vol. 40, no. 8, pp. 827-838, 2007. 
[22] M. Katsioti, D. Giannikos, P. E. Tsakiridis, and Z. Tsibouki, "Properties and hydration of blended cements with mineral alunite," Construction and Building Materials, vol. 23, no. 2, pp. 1011-1021, 2009.

[23] M. Özacar, "Phosphate adsorption characteristics of alunite to be used as a cement additive," Cement and Concrete Research, vol. 33, no. 10, pp. 1583-1587, 2003.

[24] M. Katsioti, O. Mauridou, A. Moropoulou et al., "Utilization of jarosite/alunite residue for mortars restoration production," Materials and Structures, vol. 43, no. 1-2, pp. 167-177, 2010. 

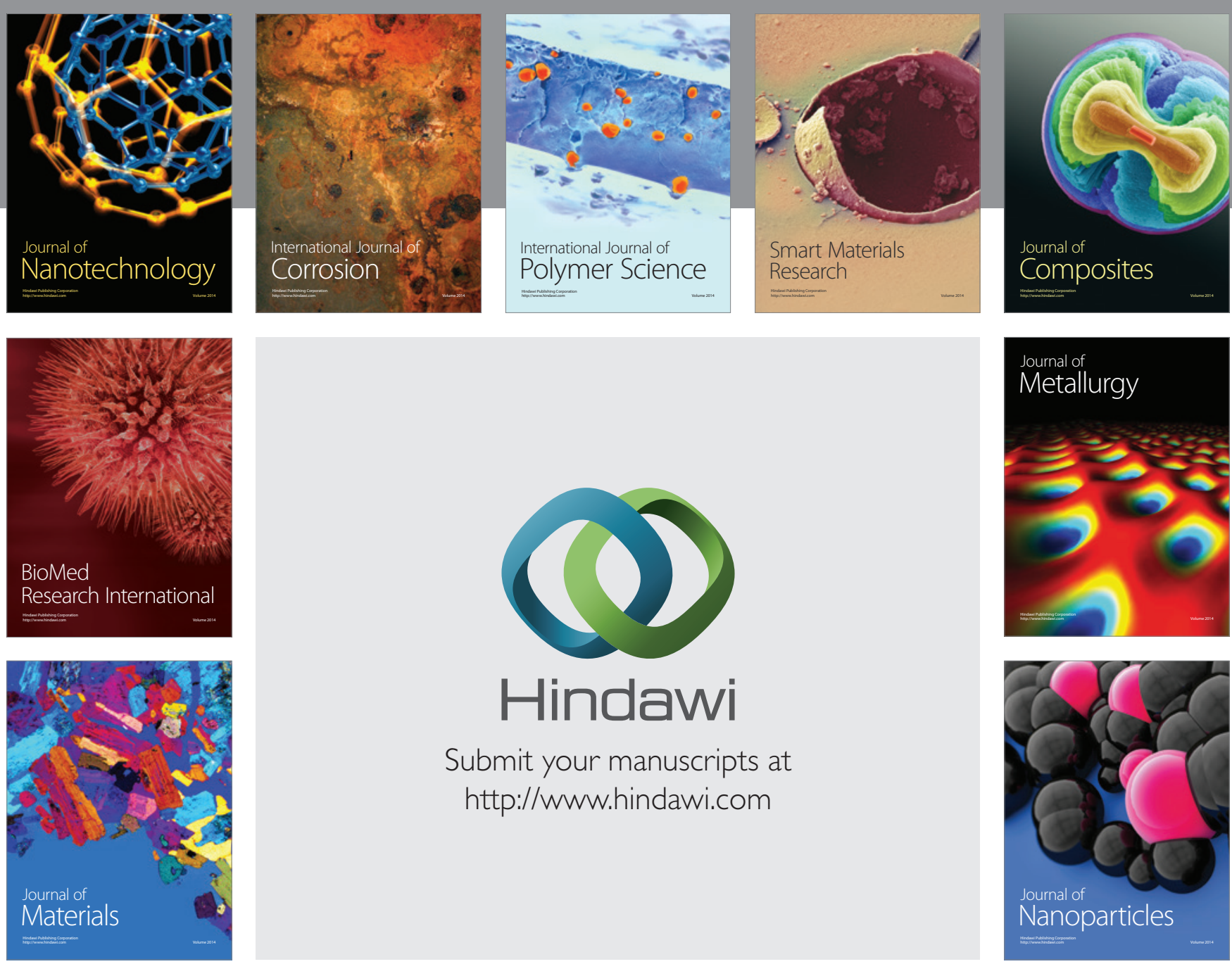

Submit your manuscripts at http://www.hindawi.com
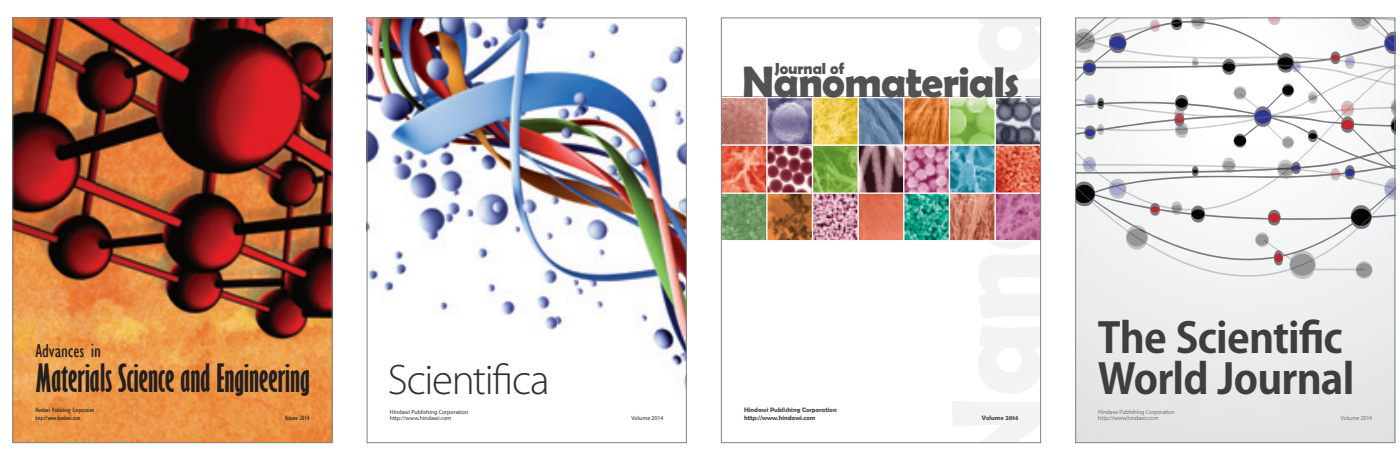

\section{The Scientific World Journal}
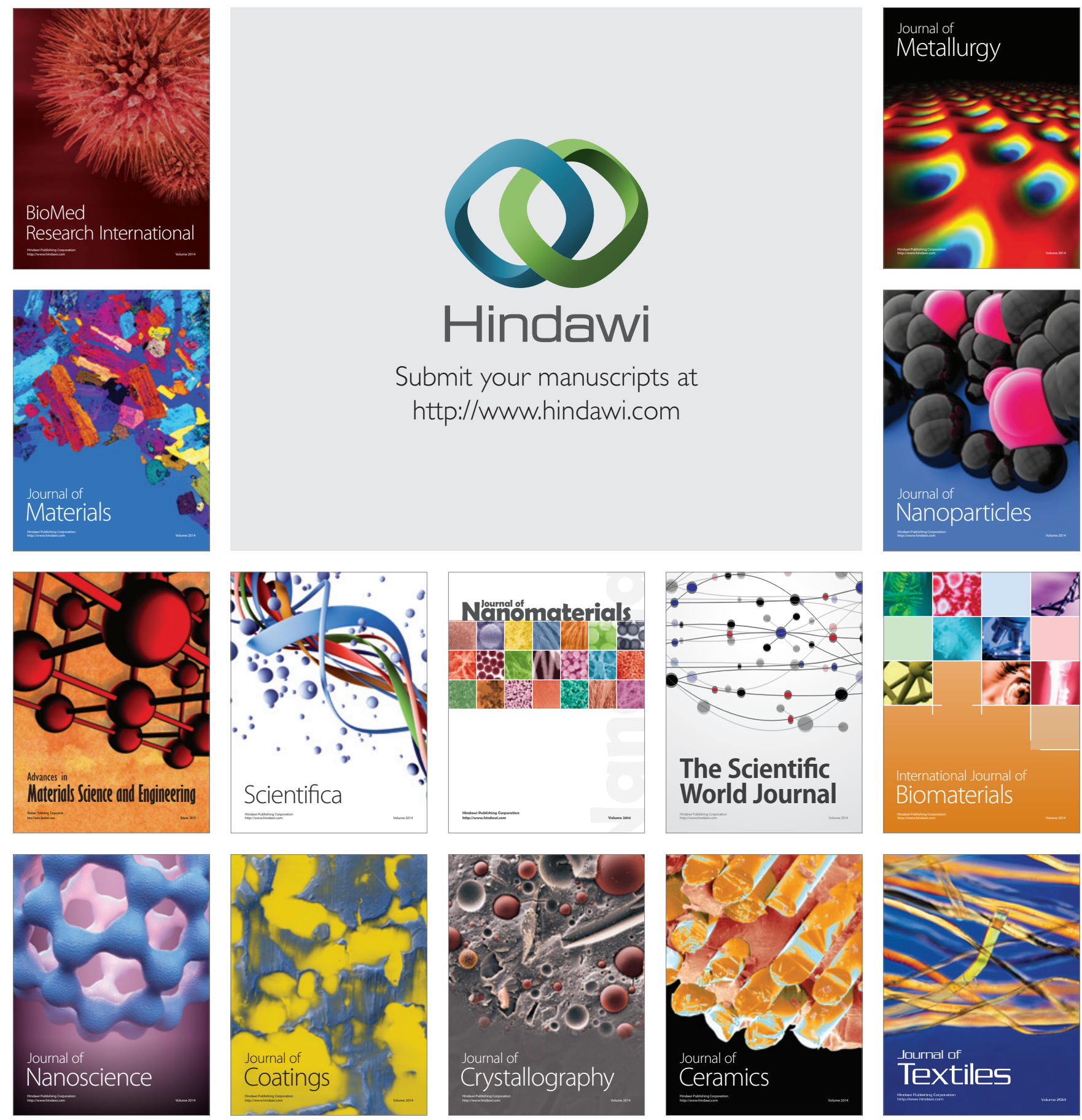